\title{
Genetic control of potassium content of common bean seeds
}

\author{
Nerison Luís Poersch(1), Nerinéia Dalfollo Ribeiro(1), \\ Daniele Piano Rosa(1) e Micheli Thaise Della Flora Possobom ${ }^{(1)}$
} (1)Universidade Federal de Santa Maria, Departamento de Fitotecnia, Avenida Roraima, no 1.000, Bairro Camobi, CEP 97105-900 Santa
Maria, RS. E-mail: nerisonp@yahoo.com.br, nerineia@hotmail.com, piano_dani@yahoo.com.br, michepossobom@yahoo.com.br

\begin{abstract}
The objective of this work was to investigate possible maternal effects on potassium content of common bean seeds, as well as to estimate the heritability and selection gains in early hybrid generations for this character and to evaluate the efficiency of genetic selection to improve the nutritional quality of common bean (Phaseolus vulgaris). Crosses with four cultivars from the Mesoamerican gene pool yielded the reciprocal $\mathrm{F}_{1}$ and $\mathrm{F}_{2}$ generations and the backcrossed populations $\left(\mathrm{BCP}_{1}\right.$ and $\left.\mathrm{BCP}_{2}\right)$. The potassium content of the progenies was measured via nitric-perchloric digestion and flame photometry. The potassium content in the tested progenies varied from 6.0 to $14.9 \mathrm{~g} \mathrm{~kg}^{-1}$ dry matter, and no significant maternal effect was observed. The narrow-sense heritability ranged from low $(33.26 \%)$ to intermediate $(43.05 \%)$. Partial dominance was observed for low potassium content in the seeds. No increase in potassium content was obtained through selection. Breeding common bean plants for increasing potassium content in seeds may be difficult because the local environment strongly influences the character.
\end{abstract}

Index terms: Phaseolus vulgaris, heritability, maternal effect, nutritional quality, selection gain.

\section{Controle genético do teor de potássio em sementes de feijão}

Resumo - O objetivo deste trabalho foi investigar um possível efeito materno no teor de potássio em sementes de feijão-comum (Phaseolus vulgaris), além de estimar a herdabilidade e o ganho na seleção em gerações precoces quanto a esse caráter e avaliar a eficiência da seleção em aumentar a qualidade nutricional do feijão. Cruzamentos entre quatro cultivares do grupo gênico Mesoamericano produziram as gerações $F_{1}$ e $F_{2}$ recíprocas e os retrocruzamentos $\left(\mathrm{RCP}_{1} \mathrm{e}\right.$ $\mathrm{RCP}_{2}$ ). $\mathrm{O}$ teor de potássio das progênies foi medido por digestão nítrico-perclórica e uso de fotometria de chama. $\mathrm{O}$ teor de potássio nas progênies testadas variou de 6,0 a $14,9 \mathrm{~g} \mathrm{~kg}^{-1}$ de matéria seca, e nenhum efeito materno significativo foi observado. A herdabilidade em sentido restrito variou de baixa $(33,26 \%)$ à intermediária $(43,05 \%)$. Foi observada dominância parcial quanto ao baixo teor de potássio nas sementes. Nenhum aumento no teor de potássio foi obtido por meio de seleção. O melhoramento para aumentar o teor de potássio em sementes de feijão-comum pode apresentar dificuldades, porque o efeito de ambiente influencia fortemente o caráter.

Termos para a indexação: Phaseolus vulgaris, herdabilidade, efeito materno, qualidade nutricional, ganho na seleção.

\section{Introduction}

Potassium deficiency in humans is rare because it is present in almost all types of food (Franco, 2005). However, cultural or social issues may restrict the human diet, leading to key mineral deficiency. Occasional $\mathrm{K}$ deficiencies are diagnosed by symptoms including renal disorder, diabetic acidosis, vomiting, diarrhea and excessive sweating (Maban \& Escott-Stump, 1998). Potassium regulates osmosis and aqueous equilibrium, which impacts nerve transmission, muscle tone, renal function, and heart muscle contraction (Franco, 2005). The Institute of Medicine recommends a dietary $\mathrm{K}$ intake of $4.7 \mathrm{~g}$ per day to satisfy the nutritional requirements of an adult individual (Institute of Medicine of the National Academies, 2004). However, people who engage in intense physical activity require higher $\mathrm{K}$ intake to maintain proper physiological function (Lindinger, 1995).

Legumes are a superior source of minerals compared to cereals (Welch et al., 2000). In Latin America, bean consumption provides 8 to $27 \%$ of the necessary $\mathrm{K}$ to satisfy the daily nutritional requirement (Pennington \& Young, 1990). Common bean (Phaseolus vulgaris L.) contains up to three times more $\mathrm{K}$ than banana (Lima et al., 2006); additionally, this staple food has fewer calories than bananas, is low-fat, low-sodium and cholesterol-free (Hosfield, 1991; Morrow, 1991).

Pesq. agropec. bras., Brasília, v.46, n.6, p.626-632, jun. 2011 
Breeding programs can also direct the selection towards low-potassium content cultivars, since it may provide health benefits for patients with kidney malfunction (Louis \& Dolan, 1970).

Common bean has a relatively large-seed $\mathrm{K}$ content. Wild and cultivated strains show a great genetic diversity, including variable $\mathrm{K}$ content. In Colombia, the maximum $\mathrm{K}$ content, observed in 119 accessions of wild common bean seeds, was $20.05 \mathrm{~g} \mathrm{~kg}^{-1}$ dry matter (DM), while $\mathrm{K}$ content at $21.25 \mathrm{~g} \mathrm{~kg}^{-1} \mathrm{DM}$ was the largest value observed in 1,031 cultivated accessions (Beebe et al., 2000). In Burundi, $\mathrm{K}$ values ranging from 4.42 to $6.31 \mathrm{~g} \mathrm{~kg}^{-1} \mathrm{DM}$ were observed among four common bean cultivars (Barampama \& Simard, 1993).

In the germplasm of common bean cultivated in Brazil, $\mathrm{K}$ values ranged from 15.10 to $24.80 \mathrm{~g} \mathrm{~kg}^{-1} \mathrm{DM}$ (Mesquita et al., 2007). Several studies have shown that both genetics and the environment influence $\mathrm{K}$ content of bean seeds (Barampama \& Simard, 1993; Moraghan \& Grafton, 2001). Therefore, a larger number of environments must be evaluated to select genotypes with higher nutritional content.

Genetic breeding is a strategy often used to increase the mineral content of common bean seeds. Controlled crossing and selection among segregation progenies resulted in content increases of $19.17 \%$ in phosphorus (Rosa, 2009), 33.64\% in calcium (Jost et al., 2009b), and $94 \%$ in iron (Jost et al., 2009a) of common bean seeds of early hybrid generations.

Common bean seed consists of a seed coat, which represents approximately $9 \%$ of the dry matter, and the embryo (cotyledons and embryonic axis), which represents the remaining 91\% (Poersch, 2010). Seed coat contains approximately $84 \%$ of the entire $\mathrm{Ca}$ content and $8 \%$ of $\mathrm{K}$ content (Moraghan \& Grafton, 2002). Hence, while most of $\mathrm{Ca}$ is stored in the seed coat, most of $\mathrm{K}$ is stored in the embryo. The Ca content of common bean seed is influenced by maternal parameters, and its phenotypic expression is delayed for one generation (Jost et al., 2009b). Consequently, selection should be implemented in the $\mathrm{F}_{3}$ seeds (embryo in $\mathrm{F}_{2}$ generation), when genetic variability is observed. Seed coat is a maternal tissue, and the cotyledons are produced by the fertilization (Ramalho et al., 2008). No studies were found to report the effect of maternal parameters on the $\mathrm{K}$ content of common bean seeds.
The influence of genetics on the $\mathrm{K}$ content of common bean seeds is unknown. Additionally, no studies have been found to address the feasibility of using genetic breeding to increase $\mathrm{K}$ content.

The objective of this work was to investigate possible maternal effects on the $\mathrm{K}$ content of common bean seeds, as well as to estimate the heritability and selection gains in early hybrid generations for the character and to evaluate the ability of genetic selection to improve the nutritional quality of common bean.

\section{Materials and Methods}

The $\mathrm{K}$ content inheritance pattern, including any possible maternal effect, was studied in hybrids obtained from crosses between four cultivars from the Mesoamerican gene pool: IAPAR 44 x Guapo Brilhante and BRS Expedito $x$ BRS Valente. The crosses were produced in a greenhouse at the Universidade Federal de Santa Maria, in Santa Maria county, RS, Brazil. The cultivars were selected from common bean accessions of the UFSM Bean Germplasm Bank, based on their different seed-K content and their agronomic value. All cultivars belong to the black commercial group and have an indeterminate growth habit, with small to medium guide development (type II) and an intermediate cycle (approximately 90 days).

An interlacing method with emasculation of the flower bud was used to obtain $50 \mathrm{~F}_{1}\left(q \mathrm{P}_{1} \mathrm{x} \delta \mathrm{P}_{2}\right)$ and $50 \mathrm{~F}_{1}$ reciprocal $\left(q \mathrm{P}_{2} \mathrm{x} \curvearrowright \mathrm{P}_{1}\right)$ seeds for each hybrid combination in the fall/winter of 2008. In the spring/ summer of 2008, natural self-fertilization of the $F_{1}$ and $F_{1}$ reciprocal plants produced $48 \mathrm{~F}_{2}$ and $48 \mathrm{~F}_{2}$ reciprocal generations, while backcrossing of the $F_{1}(+)$ to $\mathrm{P}_{1}\left(\mathrm{BCP}_{1}\right)$ and $\mathrm{F}_{1}(q)$ to $\mathrm{P}_{2}\left(\mathrm{BCP}_{2}\right)$ produced the 36 backcrossed generations. This process was repeated in the fall/winter of 2009 , so that the seeds of the $F_{1}$, $F_{1}$ reciprocal, $F_{2}, F_{2}$ reciprocal and backcrossed $\left(\mathrm{BCP}_{1}\right.$ and $\mathrm{BCP}_{2}$ ) generations could be evaluated under the same cultivation conditions.

The seeds were sown in 5-L plastic pots with two plants per pot. Pots were filled with soil, typical alitic Argisol (Argissolo Bruno-Acinzentado) with carbonized rice husks and commercial substrate was mixed at a 2:1:1 ratio according to volume. Soil fertility was corrected, and nitrogen was applied to the surface based on the chemical soil analysis. The plants were watered daily to maintain the soil water content close 
to that of field capacity. Plant disease and insect infestation were controlled as necessary to avoid compromising the normal development of common bean plants and to keep flower bud integrity.

At the growth cycle end, seeds from each generation were collected and dried in a greenhouse $\left(65\right.$ to $\left.70^{\circ} \mathrm{C}\right)$ until the average moisture content was $13 \%$. The samples were ground in a micromill to obtain particles less than $1-\mathrm{mm}$ diameter. Samples $(0.5 \mathrm{~g})$ of the raw bean flour from each generation were digested in $5 \mathrm{~mL}$ of a nitric-perchloric solution $\left(\mathrm{HNO}_{3}+\mathrm{HClO}_{4}\right.$ at a 5:1 ratio by volume). After 12 hours of cold digestion (no heat applied), the temperature was gradually elevated by $30^{\circ} \mathrm{C}$, every $30 \mathrm{~min}$, until it reached $180^{\circ} \mathrm{C}$. At the end of the digestion, when approximately $1 \mathrm{~mL}$ of the transparent solution remained, the sample was diluted by adding distilled water to a total volume of $50 \mathrm{~mL}$ according to Miyazawa et al. (1999). Approximately $20 \mathrm{~mL}$ of this dilution was removed, and the $\mathrm{K}$ content was measured by flame photometry.

The $\mathrm{K}$ content genetic study was performed in a common bean experiment, in a randomized complete block design, with five replicates (plants) for parents and $F_{1}$ reciprocal generations $\left(F_{1}\right.$ seeds), and 24 replicates (plants) for the $F_{2}$ reciprocal generations $\left(F_{2}\right.$ seeds). To test the impact of maternal effects, a comparison was made between the $\mathrm{P}_{1} \times \mathrm{P}_{2}, \mathrm{~F}_{1} \times \mathrm{F}_{1}$ reciprocal, and $\mathrm{F}_{2}$ $x \mathrm{~F}_{2}$ reciprocal mean values by Student's t-test, at 5\% probability.

The genetic parameters were estimated from the variances of the parents, and in the $\mathrm{F}_{1}, \mathrm{~F}_{2}, \mathrm{BCP}_{1}$ and $\mathrm{BCP}_{2}$ generations based on embryo generation for each hybrid combination. The broad-sense heritability $\mathrm{h}_{\mathrm{a}}^{2}=\sigma_{\mathrm{g}}^{2} / \sigma_{\mathrm{p}}^{2}$ and the narrow-sense heritability $\mathrm{h}_{\mathrm{r}}^{2}=\sigma_{\mathrm{A}}^{2} / \sigma_{\mathrm{p}}^{2}$ were estimated with the backcross method (Warner, 1952), in which the additive variance was given by $\sigma_{\mathrm{A}}^{2}=2 \sigma_{\mathrm{F}_{2}}^{2}-\left(\sigma_{\mathrm{RCP}_{1}}^{2}+\sigma_{\mathrm{RCP}_{2}}^{2}\right)$, the phenotypic variance was $\sigma_{\mathrm{P}}^{2}=\sigma_{\mathrm{F}_{2}}^{2}$, and the environmental variance in $\mathrm{F}_{2}$ was $\sigma_{\mathrm{E}}^{2}=1 / 3\left(\sigma_{\mathrm{F}_{1}}^{2}+\sigma_{\mathrm{P}_{1}}^{2}+\sigma_{\mathrm{P}_{2}}^{2}\right)$.

Heterosis in the $F_{1}$ generation was quantified as a percentage for both heterosis related to the mean of the parents by the equation $\mathrm{H} \%=\left[\left(\mathrm{F}_{1}-\mathrm{P}\right) / \mathrm{P}\right] \times 100$ and for heterobeltiosis $\mathrm{HT} \%=\left[\left(\mathrm{F}_{1}-\mathrm{MP}\right) / \mathrm{MP}\right] \times 100$, in which $\mathrm{P}=\mathrm{P}_{1}+\mathrm{P}_{2} / 2$ and $\mathrm{MP}$ is the best male parent.

To predict the selection gains, $25 \%$ of the plants with $F_{2}$ seeds were assessed (embryo in $F_{2}$ generation) which had the highest $\mathrm{K}$ content. The gain expected, when accounting for the selection and recombination of superior plants with $F_{2}$ seeds (embryo in the $F_{2}$ generation), was estimated by the following equation: $\Delta \mathrm{G}=\mathrm{DS} \times \mathrm{h}_{\mathrm{r}}^{2}$ and $\Delta \mathrm{G}(\%)=100 \Delta \mathrm{G} / \overline{\mathrm{F}}_{2}$, in which DS is the selection differential expressed by $\overline{\mathrm{X}}_{\mathrm{s}}-\overline{\mathrm{X}}_{0} ; \overline{\mathrm{X}}_{\mathrm{s}}$ is the average of selected plants with seeds in $\mathrm{F}_{2}$; and $\overline{\mathrm{X}}_{0}$ is the average of plants with seeds in $\mathrm{F}_{2}$. The statistical genetic analyses were performed with Microsoft Excel and the Genes softwares (Cruz, 2006).

\section{Results and Discussion}

In the reciprocal hybrids IAPAR $44 \mathrm{x}$ Guapo Brilhante and BRS Expedito $\mathrm{x}$ BRS Valente, the difference between the $\mathrm{K}$ content mean values for $\mathrm{P}_{1}$ and $\mathrm{P}_{2}$ was significant (Figure 1). The parents had different $\mathrm{K}$ content in seeds from those of each hybrid combination, which made it possible to obtain early hybrid generations, which were genetically variable for the K content phenotype. The existence of genetic variability enables the use of genetic improvement to increase $\mathrm{K}$ content of common bean seeds.

No significant difference was observed between the $\mathrm{K}$ content mean values for reciprocal $\mathrm{F}_{1}$ hybrids, which suggests that there was no significant maternal effect on the $\mathrm{K}$ content phenotype in common bean seeds. Poersh (2010) found approximately 83.75 to $90.04 \%$ of the whole $\mathrm{K}$ content concentrated in the embryo of common bean seeds. Due to the great mobility of K in plants (Hocking \& Pate, 1977), a large quantity of this mineral accumulates in the seed embryo.

The difference between the $F_{2}$ and $F_{2}$ reciprocal $\mathrm{K}$ content mean values was not significant, which suggests that the $\mathrm{K}$ content was similar in these seeds and is associated with the reciprocal $F_{1}$ hybrid phenotype. Thus, selection for increasing $\mathrm{K}$ content in common bean should begin with the $\mathrm{F}_{2}$ seeds (embryo in $F_{2}$ generation) because ample genetic variability was observed in this generation. Previous studies have also shown that the P content of common bean seeds is not associated with a maternal effect (Rosa, 2009). Similarly to K, P content is also concentrated mainly in the seeds of common bean embryos (Moraghan \& Grafton, 2002).

A breakdown of the phenotypic variance observed in the present study showed that the environment markedly influenced the K content of the IAPAR 44 x Guapo Brilhante hybrid (Table 1). Because the environment was responsible for most of the phenotypic variance 
detected, an intermediate broad-sense heritability $\left(\mathrm{h}_{\mathrm{a}}^{2}=44.08 \%\right)$ was observed. Correspondingly, the narrow-sense heritability was low $\left(\mathrm{h}_{\mathrm{r}}^{2}=33.26 \%\right)$ because the additive variance did not constitute a great proportion of all genetic variance, and the environment exerted significant effects, which indicates that the $\mathrm{K}$ content had a high noncontrollable influence; therefore, this trait is not favorable for selection. Genotype,

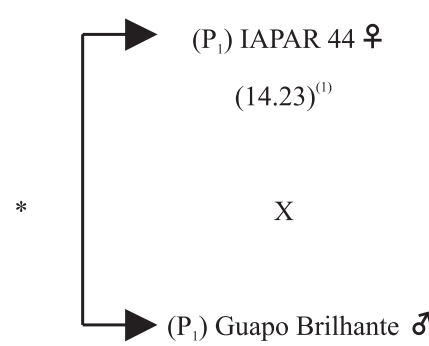

(11.79)

$\left(\mathrm{P}_{1}\right)$ Guapo Brilhante 우

(11.79)

$\mathrm{X}$

$\left(\mathrm{P}_{1}\right)$ IAPA44 ठ゙

(14.23)

$\left(\mathrm{P}_{1}\right)$ BRS Expedito 우
$(14.09)^{(1)}$
$\left(\mathrm{P}_{2}\right)$ BRS Valente ठำ $^{7}$
$(11.55)$
$\left(\mathrm{P}_{2}\right)$ BRS Valente 우
$(11.55)$
$\mathrm{X}$

$\left(\mathrm{P}_{1}\right)$ BRS Expedito $\sigma^{\pi}$ (14.09)
Hybrid 1

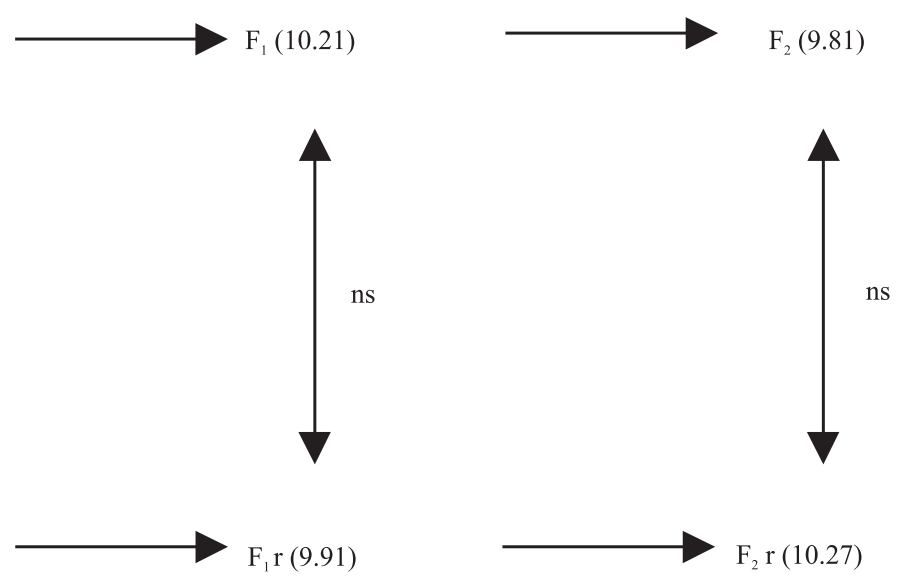

Hybrid 2
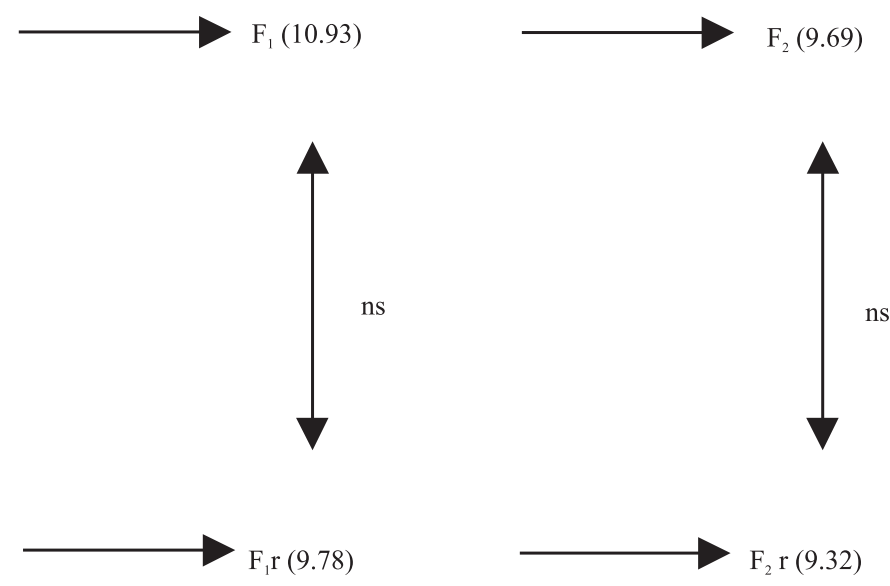

Figure 1. Breeding and selection process schematics for $\mathrm{K}$ content of common bean seeds of the IAPAR $44 \mathrm{x}$ Guapo Brilhante and BRS Expedito $\mathrm{x}$ BRS Valente hybrids. The mean $\mathrm{K}$ content $\left(\mathrm{g} \mathrm{kg}^{-1}\right.$ of dry matter) is in parentheses. $\mathrm{P}_{1}$ and $\mathrm{P}_{2}$ are the parental seeds, $F_{1} r$ is the $F_{1}$ and $F_{1}$ reciprocal seeds, and $F_{2} r$ is the $F_{2}$ and $F_{2}$ reciprocal seeds; the significance level for differences in mean values was evaluated for $\mathrm{P}_{1} \times \mathrm{P}_{2}, \mathrm{~F}_{1} \times \mathrm{F}_{1}$ reciprocal, and $\mathrm{F}_{2} \times \mathrm{F}_{2}$ reciprocal from the IAPAR 44 x Guapo Brilhante and BRS Expedito x BRS Valente hybrids. ${ }^{(1)}$ Potassium content ( $\mathrm{g} \mathrm{kg}^{-1}$ of DM); ns, Nonsignificant. *Significant by Student's test, at $5 \%$ probability. 
environment and genotype $\mathrm{x}$ environment interaction affect mineral accumulations in common bean seed (Barampama \& Simard, 1993). Hence, selection of common bean germplasm with elevated $\mathrm{K}$ content in the seed may be difficult within this early hybrid generation.

Nevertheless, in the BRS Expedito x BRS Valente hybrid, the effect of genetic variance was greater. A large broad-sense heritability was obtained $\left(\mathrm{h}^{2} \mathrm{a}\right.$ : 79.97\%). An intermediate narrow-sense heritability $\left(h^{2} r: 43.05 \%\right)$ was observed because additive variance represented approximately half of the genetic variance. Additive variance is an important parameter for improving autogamous plants because it does not segregate from generation to generation, which makes it possible to successfully select for specific traits in segregating populations (Carvalho et al., 2001).

To our knowledge, there are no previous studies describing the heritability of $\mathrm{K}$ content in common bean seeds. Previous studies have shown that the P content in seeds of common bean has a narrow-sense heritability ranging from a low $(21.37 \%)$ to intermediate values (65.54\%) (Rosa, 2009). For Ca content of common bean seeds, narrow-sense heritability estimates from intermediate $(47 \%)$ to high $(63.61 \%)$ values were

Table 1. Genetic parameters and predicted selection gains in $\mathrm{K}$ content for the common bean seeds of the IAPAR $44 \mathrm{x}$ Guapo Brilhante and BRS Expedito $\mathrm{x}$ BRS Valente hybrids.

\begin{tabular}{lcc}
\hline Estimate & \multicolumn{2}{c}{$\mathrm{K}$ content $\left(\mathrm{g} \mathrm{kg}^{-1}\right)$} \\
\cline { 2 - 3 } & $\begin{array}{c}\text { IAPAR } 44 \times \text { Guapo } \\
\text { Brilhante }\end{array}$ & $\begin{array}{c}\text { BRS Expedito } x \\
\text { BRS Valente }\end{array}$ \\
\hline Mean & 11.03 & 10.69 \\
Environmental coefficient of variation $(\%)$ & 16.83 & 13.25 \\
Phenotypic variance $\left(\sigma_{\mathrm{P}}^{2}\right)$ & 3.22 & 3.17 \\
Parent 1 variance $\left(\sigma^{2} \mathrm{P}_{1}\right)$ & 0.31 & 0.08 \\
Parent 2 variance $\left(\sigma^{2} \mathrm{P}_{2}\right)$ & 1.24 & 0.20 \\
$\mathrm{~F}_{1}$ variance $\left(\sigma^{2} \mathrm{~F}_{1}\right)$ & 3.86 & 1.62 \\
Environmental variance $\left(\sigma_{\mathrm{E}}^{2} \mathrm{~F}_{2}\right)$ & 1.80 & 0.64 \\
Genetic variance $\left(\sigma_{\mathrm{G}}^{2}\right)$ & 1.42 & 2.53 \\
Additive variance $\left(\sigma_{\mathrm{A}}^{2}\right)$ & 1.07 & 1.36 \\
Broad-sense heritability $\left(\mathrm{h}_{\mathrm{a}}^{2}\right)$ & 44.08 & 79.97 \\
Narrow-sense heritability $\left(\mathrm{h}_{\mathrm{r}}^{2}\right)$ & 33.26 & 43.05 \\
Heterosis $(\mathrm{H} \%)$ & -21.50 & -14.74 \\
Heterobeltiosis $\mathrm{P}_{1}(\mathrm{HT} \%)$ & -28.21 & -22.44 \\
Maximum value in parents & 14.90 & 14.40 \\
Minimum value in parents & 10.50 & 11.05 \\
Maximum value in $\mathrm{F}_{2}$ & 14.30 & 13.80 \\
Minimum value in $\mathrm{F}_{2}$ & 6.80 & 6.00 \\
Selection differential $(\mathrm{SD})$ & 2.52 & 2.43 \\
Selection gain $(\Delta \mathrm{G} \%)$ & 7.98 & 10.65 \\
Predicted mean after the first selection cycle & 11.36 & 10.90 \\
\hline & & \\
\hline & &
\end{tabular}

obtained with the Pérola $\mathrm{x}$ TPS Bonito and TPS Bonito x BRS Expedito hybrids, respectively (Jost et al., 2009b). Because heritability is not a fixed characteristic, variations can occur depending on the evaluated population, the selected character and the genetic variability.

Since environment exerts a large effect on the phenotype, and a low to intermediate narrow-sense heritability was observed, the $\mathrm{K}$ content appears to exhibit a quantitative inheritance (Table 1). Thus, genetic selection for this trait should be difficult. The efficiency of hybridization was low, and low population sizes were obtained for replicates of the $\mathrm{F}_{2}$ generations and backcrosses $\left(\mathrm{BCP}_{1}\right.$ and $\left.\mathrm{BCP}_{2}\right)$, which hindered a more in-depth study on the genetic effects and the number of genes which control $\mathrm{K}$ content.

For heterosis, negative values in two of the hybrids were observed (Table 1). The mean value for the $F_{1}$ generation was lower compared to those of the parents (Figure 1), which may support a super-dominance hypothesis. Because common bean is self-fertilizing, heterosis is expected to be reduced by half in each self-fertilizing generation. For this reason, the $\mathrm{F}_{3}$ generation may have lower values compared to the $F_{2}$ because of an increase in homozygosis. Further studies with analysis of the advanced generations are needed to assess the segregation of this parameter.

The $\mathrm{K}$ content values showed continuous distributions in early generations and ranged from $6.0 \mathrm{~g} \mathrm{~kg}^{-1} \mathrm{DM}\left(\mathrm{F}_{2}\right.$ seeds from BRS Expedito $\mathrm{x}$ BRS Valente hybrid) to $14.9 \mathrm{~g} \mathrm{~kg}^{-1} \mathrm{DM}$ (maximum value observed in the parents) (Table 1). These values are higher than those previously reported in Burundi (Barampama \& Simard, 1993), but lower than the values observed in genotypes in Colombia (Beebe et al., 2000) and Brazil (Mesquita et al., 2007). These differences may be related to genetic and environmental variability, to genotype-environment interactions, and to the soil type or fertilization use.

Plants with low $\mathrm{K}$ content in the seeds were identified in the $F_{1}$ and $F_{2}$ generation seeds, which indicates that there was a partial dominance for low $\mathrm{K}$ content in the common bean seeds (Table 1). Partial dominance for low protein (Polignano, 1982) and cysteine content (Ribeiro et al., 2009) has already been described in common bean. Epistatic effects may impact the $\mathrm{K}$ content phenotype and make genetic selection of genotypes of a higher nutritional quality even more difficult. Epistatic variance relates to the interaction 
of alleles at different loci, which can be erroneously detected as an additive variance by statistical methods (Holland, 2001). In the present study, transgressive segregation was observed, and plants with low-seed $\mathrm{K}$ content were obtained. This result is important for selecting low-K content common bean which can be useful for kidney malfunction patients. After the first selection cycle of the IAPAR 44 x Guapo Brilhante and BRS Expedito x BRS Valente hybrids, the selection gain predicted increases of 7.98 and $10.65 \%$ in $\mathrm{K}$ content (11.36 and $10.90 \mathrm{~g} \mathrm{~kg}^{-1} \mathrm{DM}$, respectively) were expected, assuming that $25 \%$ of the plants, with the highest $\mathrm{K}$ content in the $\mathrm{F}_{2}$ seeds, were retained. However, it was expected that the selection gains would be low because dominance for low $\mathrm{K}$ content was observed.

It was not possible to increase the $\mathrm{K}$ content of common bean seeds, by controlled crossing and selection among segregating progenies, using the four parents tested in this study. However, $\mathrm{F}_{2}$ seeds with $\mathrm{K}$ content similar to the IAPAR 44 and BRS Expedito parents were observed (Table 1).

\section{Conclusions}

1. The early generation narrow-sense heritability for the potassium content in the seeds of common bean is low to intermediate, and there is no maternal effect on the expression of this phenotype using the tested parents in this study.

2. Genetic selection of common bean germplasm, with increased potassium content in the seeds, may be difficult because of the strong environment influence on this phenotype.

\section{References}

BARAMPAMA, Z.; SIMARD, R.E. Nutrient composition, protein quality and antinutritional factors of some varieties of dry beans (Phaseolus vulgaris) grown in Burundi. Food Chemistry, v.47, p.159-167, 1993.

BEEBE, S.; GONZALEZ, A.V.; RENGIFO, J. Research on trace minerals in the common bean. Food and Nutrition Bulletin, v.21, p.387-391, 2000.

CARVALHO, F.I.F. de; SILVA, A.S.; KUREK, A.J.; MARCHIORO, V.S. Estimativas e implicações da herdabi-lidade como estratégia de seleção. Pelotas: UFPEL, 2001. 98p.

CRUZ, C.D. Programa Genes. Viçosa: UFV, 2006. 382p.

FRANCO, G. Tabela de composição química dos alimentos. 9.ed. Rio de Janeiro: Atheneu, 2005. 307p.
HOCKING, P.J.; PATE, J.S. Mobilization of minerals to developing seeds of legumes. Annals of Botany, v.41, p.1259-1978, 1977.

HOLLAND, J.B. Epistasis and plant breeding. Plant Breeding Reviews, v.21, p.27-92, 2001.

HOSFIELD, G.L. Genetic control of production and food quality factors in dry bean. Food Technology, v.45, p.98-103, 1991.

INSTITUTE OF MEDICINE OF THE NATIONAL ACADEMIES. Dietary reference intakes for water, potassium, sodium, chloride, and sulfate. Washington: The National Academies, 2004. 618p.

JOST, E.; RIBEIRO, N.D.; CERUTTI, T.; POERSCH, N.L.; MAZIEIRO, S.M. Potencial de aumento do teor de ferro em grãos de feijão por melhoramento genético. Bragantia, v.68, p.35-42, 2009a.

JOST, E.; RIBEIRO, N.D.; MAZIERO, S.M.; CERUTTI, T.; ROSA, D.P. Efeitos gênicos do teor de cálcio em grãos de feijão. Ciência Rural, v.39, p.31-37, 2009b.

LIMA, D.M.; COLUGNATI, F.A.B.; PADOVANI, R.M.; RODRIGUEZ-AMAYA, D.B.; SALAY, E.; GALEAZZI, M.A.M. Tabela brasileira de composição de alimentos. 2.ed. Campinas: UNICAMP, 2006. 113p

LINDINGER, M.I. Potassium regulation during exercise and recovery in humans: implications for skeletal and cardiac muscle. Journal of Molecular and Cellular Cardiology, v.27, p.1011-1022, 1995.

LOUIS, C.J.; DOLAN, E.M. Removal of potassium in potatoes by leaching. Journal of the American Dietetic Association, v.57, p.42-43, 1970.

MABAN, L.K.; SCOTT-STUMP, S. Krause: alimentos, nutrição e dietoterapia. 9.ed. São Paulo: Roca, 1998. 1179p.

MESQUITA, F.R.; CORRÊA, A.D.; ABREU, C.M.P. de; LIMA, R.A.Z.; ABREU, A. de F.B. Linhagens de feijão (Phaseolus vulgaris L.): composição química e digestibilidade protéica. Ciência e Agrotecnologia, v.31, p.1114-1121, 2007.

MIYAZAWA, M.; PAVAN, M.; MURAOKA, T.; CARMO, C.A.F. de S. do; MELLO, W.J. de. Análises químicas de tecido vegetal. In: SILVA, F.C. da. Manual de análises químicas de solos, plantas e fertilizantes. Brasília: Embrapa Comunicação para Transferência de Tecnologia, 1999. p.171-223.

MORAGHAN, J.T.; GRAFTON, K. Distribution of selected elements between the seed coat and embryo of two black bean cultivars. Journal of Plant Nutrition, v.25, p.169-176, 2002.

MORAGHAN, J.T.; GRAFTON, K. Genetic diversity and mineral composition of common bean seed. Journal of the Science of Food and Agriculture, v.81, p.404-408, 2001.

MORROW, B. The rebirth of legumes. Food Technology, v.45, p.96-121, 1991.

PENNINGTON, J.A.T.; YOUNG, B. Sodium, potassium, calcium, phosphorus and magnesium in foods from the United States total diet study. Journal of Food Composition and Analysis, v.3, p.145-165, 1990. 
POERSCH, N.L. Distribuição de minerais e genética dos teores de potássio e de cobre em sementes de feijão. 2010. 54p. Dissertação (Mestrado) - Universidade Federal de Santa Maria, Santa Maria.

POLIGNANO, G.B. Breeding for protein percentage and seed weight in Phaseolus vulgaris L. Journal of Agricultural Science, v.99, p.191-197, 1982.

RAMALHO, M.A.P.; SANTOS, J.B. dos; PINTO, C.A.B.P. Genética na agropecuária. 4.ed. Lavras: UFLA, 2008. 464p.

RIBEIRO, N.D.; LONDERO, P.M.G.; CARGNELUTTI FILHO, A.; POERSCH, N.L.; MAZIERO, S.M. Composição de aminoácidos em gerações precoces de feijão obtidas a partir de cruzamentos controlados com parental de alto teor de cisteína. Ciência Rural, v.39, p.364-370, 2009.

ROSA, S.S. Genética dos teores de fósforo e de zinco em sementes de feijão. 2009. 45p. Dissertação (Mestrado) - Universidade Federal de Santa Maria, Santa Maria.

WARNER, J.N. A method for estimating heritability. Agronomy Journal, v.44, p.427-430, 1952.

WELCH, R.M.; HOUSE, W.A.; BEEBE, S.; CHENG, Z. Genetic selection for enhanced bioavailable levels of iron in bean (Phaseolus vulgaris L.) seeds. Journal of Agricultural and Food Chemistry, v.48, p.3576-3580, 2000.

Received on January 9, 2011 and accepted on May 3, 2011 